\title{
The Effect of Socialization, Sanction, and E-Filing on Annual SPT Reporting
}

\author{
I Nyoman Simpen ${ }^{1, *}$, Muhammad Nur Abdi ${ }^{2}$, Mochammad Fahlevi ${ }^{1 *}$, Rinto Noviantoro ${ }^{3}$, and Muhtar ${ }^{4}$ \\ ${ }^{1}$ Department of Management, Faculty of Economics, School of Business Kusuma Negara, Jakarta - Indonesia \\ ${ }^{2}$ Department of Finance, Faculty of Economics, University of Muhammadiyah, Makassar - Indonesia \\ ${ }^{3}$ Department of Accounting, Faculty of Economics, University of Dehasen, Bengkulu - Indonesia \\ ${ }^{4}$ Department of Finance, Faculty of Economics, University of Bosowa, Makassar - Indonesia
}

\begin{abstract}
Understanding to fill the tax return, annual report tax return individual is still lacking, many taxpayers did not understand how to fill out an annual tax return, especially the tax year 2014. The objective was to investigate the influence of socialization Tax, Tax Penalties and Tax e-filing of the tax return reporting annual individual taxpayer. Sampling was done by purposive sampling method and selection of non-random manner convenience. The primary data collection method used is survey method using a questionnaire. Data were analyzed using multiple linear analysis, descriptive analysis and to test hypotheses.
\end{abstract}

Keywords: Socialization Taxes; E-Filing; Tax Returns; Annual Reporting; Law.

\section{Introduction}

State revenue from the tax sector is very large, especially from individual taxpayers, but tax compliance is still not optimal. This happens because of the lack of enforcement of tax sanctions, the implementation of tax socialization and tax e-filing conducted by the government and private parties against taxpayers. At present sanctions against individual taxpayers who do not report annual tax returns are a fine of Rp. 100,000 For certain communities over a fine of Rp. One hundred thousand might be considered immaterial.

For individual taxpayers who must pay taxes, the tax liability is considered a heavy burden due to lack of socialization, both in print and electronic media for the benefits of paying taxes to the state. Besides the reasons above there are trigger factors, namely for people who have income businesses but have not yet registered to make a Taxpayer Identification Number (NPWP) card, do not report annual tax returns and do not receive sanctions from the government. This is where the important role of sanctions and socialization by the government and the private sector to provide understanding to report the annual tax return.

E-filing is the electronic submission of annual tax returns instead of manual paper use, which is directly connected to the tax system in Indonesia, which is carried out on-line in real-time via the website of the Directorate General of Taxes.

Tax socialization is the delivery of information from the directorate general of taxes in the form of new regulations to taxpayers using seminars, conveying through banners or electronic media including tax sanctions. Tax Sanctions are administrative fines or penalties given by the tax authorities to taxpayers for not fulfilling their tax obligations [1]. There are two types of tax sanctions, namely administrative sanctions and criminal sanctions. Administrative sanctions are caused because taxpayers do not or are late from the specified deadline to submit SPT to the Tax Service Office. While criminal sanctions because taxpayers deliberately do not report tax returns that can cause harm to the State. The submission of annual tax returns for individuals can also be through e-filing. E-filing is the electronic submission of annual tax returns instead of manual paper use, which is directly connected to the tax system in Indonesia. To be able to submit an annual SPT a person with e-filing must first register to get an e-fin (electronic filing identification number).

a) Does the tax socialization affect the reporting of the annual personal tax return for the 2014 tax year?

b) Does the Tax sanction affect the submission of an annual personal tax return for the 2014 tax year?

c) Does the Tax e-filing system affect the reporting of the 2014 Annual Personal Tax Return?

\section{Literature Review}

\subsection{Regulation Theory}

The regulatory theory is a theory that emphasises the existence of government intervention in the economic centre for the public benefit [2]. This theory arises because of market failure, so the government intervened

\footnotetext{
*orresponding author: fahlevi@,stie-kusumanegara.ac.id
} 
by issuing several regulations. Market failures can be caused by:

a) There is no competition

b) There is an imbalance of market information to market participants

c) The high cost of reliable information so that the distribution of information is different - different so that the difference in response to the market

d) An agent game

e) The government is not neutral in issuing regulations (still influenced by the strength of certain groups).

In Indonesia, regulations can be in the form of laws, government regulations (PP), presidential decrees (Kepres), and others. In short, the flow of Taxation Regulations starts with the Law, which is approved by the People's Representative Council together with the President, then stipulated in a Government Regulation (PP), continued and affirmed by the Minister of Finance Regulation (PMK) and continued with the technical procedures and implementation, which is regulated in Director General Regulations Tax (PER).

As for the characteristics of regulatory theory:

a) Lack of competition (monopoly)

b) Information gap (Information Asymmetry)

c) There are Agents (entrepreneurial politicians and public interest groups).

\subsection{Theory of Interest}

The greater the community or population's interest in the country, the higher the tax that must be paid or paid [3]. This theory is practised by the tax authorities to collect taxes. At present security and the situation are increasingly uncertain, even in other countries there is still a civil war between the rebels with the official government. When this situation occurs, the government must increase defence, for example to buy fighter aircraft and be equipped with sophisticated weaponry. To be able to finance weapons to increase security in the community.

\subsection{Definition of Tax Dissemination, Tax Sanctions and Tax E-filing}

Socialization means a technique for delivering information to several people or groups of people through seminars, workshops, counseling and using certain media for specific purposes. Tax socialization programs to convey information related to new regulations that have been carried out by the Directorate General of Taxes, covering seminars in buildings that are followed by taxpayers starting from entrepreneurs, professional experts such as tax consultants, and law. Besides, counseling is carried out by the Directorate General of Taxes by inviting private and governmental parties. Another way to do this is to put up banners related to taxes, air public service announcements that contain knowledge and limits on the submission of tax returns on electronic media such as television.

Tax Sanctions, namely administrative fines or penalties given by the tax authorities to taxpayers for not carrying out tax obligations [1]. Stressed in Law Number
36 Year 2008 article 19 paragraph 1 letter k: Administrative sanctions in the form of interest, fines, and increases and criminal sanctions in the form of confinement relating to the implementation of legislation in the field of taxation.

Tax e-filing is the electronic delivery of tax returns with the help of the internet instead of using paper, which is directly connected to the tax software system in Indonesia.

\subsection{Research Framework}

The important things that must be considered so that the thought framework can be used as a benchmark are as follows:

a) Theories used in observing and explaining the problems described by researchers when writing a literature review. The author must be able to choose a theory that is relevant to the problem under study and can provide opinions and reasons why to choose a written theory.

b) The author must be able to describe the concepts and relationships between variables so that it is clear when solving problems.

The research problems raised by the author are:

a) Will tax socialization affect the 2014 annual tax return?

b) Does the tax sanction affect the 2014 annual tax return?

c) Does tax e-filing affect the 2014 annual tax return?

Based on the problem written above, the writer chooses regulatory theory as a grand theory. The regulatory theory was chosen because there was government intervention to issue regulations in the area of tax socialization, tax witnesses, and the tax e-filing system. The regulatory theory also explains the public policy that is closely related to the policies issued by the government to regulate taxpayers and tax collectors or tax cut reported in Annual Tax Returns (SPT), especially individual taxpayers. Relationship of each variable.

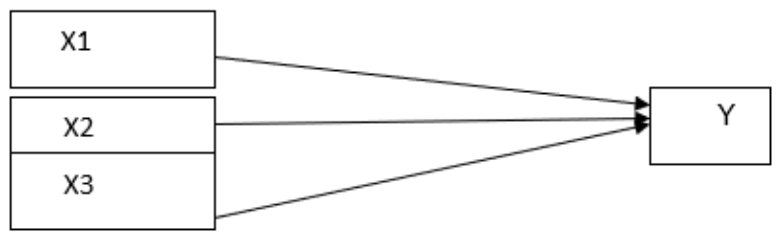

Fig. 1. Framework

$$
\begin{aligned}
& \text { Information: } \\
& X 1=\text { Tax Socialization } \\
& X 2=\text { Tax Sanction } \\
& X 3=\text { Tax e-filing } \\
& Y=\text { Accuracy of } 2014 \text { SPT Reporting. }
\end{aligned}
$$

\subsection{Hypothesis}

Constructing a hypothesis is a challenge that must be faced by the author because it must be able to relate the relevance of the research problem (phenomenon) to the underlying theory and thought framework. The 
hypothesis is a provisional conjecture by the authors regarding the prediction of phenomena or the relationship between phenomena. A hypothesis is often explained as a temporary conjecture that must be verified through scientific research. Relationship hypothesis is a statement about the relationship between two variables. Tax socialization is currently being intensively carried out by the Directorate General of Taxes.

The phenomenon is that tax regulations often change. Tax officials at KPP often do tax socialization so that taxpayers can understand the contents of the new regulations issued by the Ministry of Finance and the Director-General of taxes. In 2015 there was also a remission of tax sanctions following PMK 29/03/2015 and PMK 91 / PMK / 03/2015. Likewise, e-filing has become a breakthrough by the Director-General of Taxes to improve the timeliness of submitting annual tax returns for individuals and tax returns for corporate taxpayers. The author connects the existing phenomena with the theory and thought framework to produce several hypotheses as follows:

a) H1 Tax socialisation affects the annual tax return report for the 2014 tax year.

b) H2 Tax sanctions affect the annual tax return of the 2014 tax year.

c) H3 Tax e-filing affects reporting tax returns for the 2014 tax year.

\section{Methodology}

This type of research used by researchers is the type of causality that aims to test the hypothesis about the effect of one or several independent variables (independent variables) on the dependent variable (the dependent variable). This study uses individual data that is giving several questionnaires related to the title above to several samples from the population of accounting masters at Mercu Buana University, Menteng campus in the 2014/2015 school year. The population of accounting students in the employee program class at the Menteng campus is 203 students. To determine the sample the researcher used the Slovin formula so that 135 respondents were obtained. The reason for using primary data is because the sample of the object under study has worked, already has a TIN, some respondents have used e-filing to report the annual SPT of a private person, already understand the term taxation and earn income from the employer. Besides, the data is of more quality because the respondents are graduates. Postgraduate students of Mercu Buana University on the Menteng campus come from various cities in Indonesia (domicile places), some come from Bogor, Tangerang, Jakarta, Bekasi, and Depok.

The population is the group that is the study for research (now, 2000; 266). The population in this study were students majoring in accounting at the Mercu Buana University Menteng campus in the 2014/2015 school year. Sekaran [4] defines the sample as being part of the population obtained based on population selection. The sampling technique is done by purposive sampling and the selection of nonprobability (non-random selection) one way is done by the Convenience method (samples that want to return the questionnaire). The population is 203 students, the number of samples to be studied 135 samples. One to calculate determines the number of samples, according to Slovin [5].

The selection of data uses a questionnaire technique that is distributed to each student of Mercu Buana University majoring in accounting at the Menteng campus. Choosing a sample at the Menteng campus university is based because students already work and have an income. Besides, the average student already has a TIN. From the aspect of education, all of them are undergraduate graduates, so the information on research objects is more accurate. Besides, several respondents have the potential to use e-filing to report personal annual tax returns for the 2014 tax year. Because they work for companies that have large numbers of employees.

\section{Result}

From the research sample data, the variable Tax Dissemination, tax e-filing, and SPT (Notification) personal report, the smallest value is 3 , while the variable minimum tax sanction is 3 . The minimum value occurs because some respondents chose the column do not agree when filling out questionnaire answers. Disagreement can be caused by the opinion of respondents not agree with the questions written in the questionnaire.

Table 1 Description of tax socialization variables, tax sanctions, tax e-filing and timeliness of reporting individual tax returns.

Table 1. Descriptive Statistics

\begin{tabular}{|l|c|c|c|c|c|}
\hline & $\mathrm{N}$ & $\begin{array}{c}\text { Mini } \\
\text { mum }\end{array}$ & $\begin{array}{c}\text { Maxi } \\
\text { mum }\end{array}$ & Mean & $\begin{array}{c}\text { Std. } \\
\text { Deviatio } \\
\mathrm{n}\end{array}$ \\
\hline Socialization & 135 & 3,00 & 15,00 & 11,4519 & 1,89940 \\
Sanction & 135 & 3,00 & 15,00 & 10,4000 & 1,84148 \\
E-Filing & 135 & 3,00 & 15,00 & 10,8370 & 1,98955 \\
SPT & 135 & 3,00 & 15,00 & 11,1185 & 1,99272 \\
Reporting & & & & & \\
$\begin{array}{l}\text { Valid N } \\
\text { (listwise) }\end{array}$ & 135 & & & & \\
\hline
\end{tabular}

While the maximum value on the socialization variable, sanctions, e-filing, SPT reporting is 15 because the highest interval value is five while the number of questions for each variable is three questions some respondents agree with all with questions on the questionnaire that have been read and filled out by respondents. The average value of the tax socialization variable is 11.4519 with a standard deviation of 1.89940 , the average value of the tax sanction variable is 10,4000 with a standard deviation of 1.84148 , the average value of tax e-filing is 10,8370 with standard deviation of 1.98955 and the average personal income tax report value of 11.1185 with a standard deviation of 1.99272 . 


\subsection{Hypothesis Test}

Table 2. Model Summary

\begin{tabular}{|l|c|r|r|c|}
\hline Model & $\mathrm{R}$ & $\begin{array}{c}\mathrm{R} \\
\text { Square }\end{array}$ & $\begin{array}{c}\text { Adjusted R } \\
\text { Square }\end{array}$ & $\begin{array}{c}\text { Std. The } \\
\text { error of the } \\
\text { Estimate }\end{array}$ \\
\hline 1 & $.356^{\mathrm{a}}$ & .127 & .107 & 1.88312 \\
\hline
\end{tabular}

Variation of the variables used in this research model can explain the variation of the dependent variable on the timeliness of the annual SPT reporting of individuals can be explained by an independent variable of $10.7 \%$ (tenpoint seven percent) the remaining $89.3 \%$ allegedly explained by the variables Other variables not included in the regression model such as: tax officer service, culture, respect for the government, behavior, honesty, law, fiscal policy, auditor findings, tax rates, income and religious values (religious).

\subsection{T-Test}

Table 3. Coefficients

\begin{tabular}{|c|c|c|c|c|c|}
\hline \multirow[t]{2}{*}{ Model } & \multicolumn{2}{|c|}{$\begin{array}{l}\text { Unstandardized } \\
\text { Coefficients }\end{array}$} & \multirow{2}{*}{$\begin{array}{c}\begin{array}{c}\text { Standardi } \\
\text { sed } \\
\text { Coefficie } \\
\text { nts }\end{array} \\
\text { Beta }\end{array}$} & \multirow[t]{2}{*}{$\mathrm{T}$} & \multirow[t]{2}{*}{ Sig. } \\
\hline & B & $\begin{array}{l}\text { Std. } \\
\text { Error }\end{array}$ & & & \\
\hline (Constant) & 9,351 & 1,529 & & 6,115 & ,000 \\
\hline $\begin{array}{l}\text { Sozializatio } \\
\mathrm{n}\end{array}$ &, 100 &, 091 & ,095 & 1,103 & ,272 \\
\hline Sanction & , 196 & ,090 &,- 181 & 2,163 &, 032 \\
\hline $\begin{array}{l}\text { E-Filing } \\
\operatorname{Tax}\end{array}$ & ,245 & ,087 & ,245 & 2,807 &, 006 \\
\hline
\end{tabular}

Of the three independent variables included in the regression model, only the tax socialization variable has an insignificant influence on the annual tax return reporting of individuals. The probability of the significance of the tax socialization variable is $0.272>$ 0.05 . While the probability of a tax sanction variable is $0.032<0.05$ and the tax e-filing variable produces a probability of $0.006<0.05$. Seeing the results of calculations with SPSS, it can be concluded at a significance level of 0.05 independent variables affecting the annual reporting of the individual's annual tax return. Statistically, the following equation is obtained:

$$
\mathrm{Y}=9,351+0,100 \mathrm{X} 1+0,196 \times 2+0,245 \times 3+e
$$

Information:

$Y=$ timeliness of SPT reporting

$X 1=$ tax socialization

$X 2=$ tax sanction

$X 3=e$-filing $\operatorname{tax}$

$e=$ error.

\subsection{Discussion}

The tax sanction free variable has a sig value of 0.032 , which is smaller than 0.005 , which means that the tax sanction partially has a significant effect on the timely reporting of individual tax returns. Hypothesis $\mathrm{H} 2$ (tax sanctions affect the timeliness of the 2014 Annual Personal Tax Return Reporting) is accepted. This is caused by many respondents who choose to agree because tax sanctions are enforced or implemented to the maximum can affect the reporting of the 2014 tax return. Also, the most severe sanctions are sanctions in the form of imprisonment in prison. This is the cause of sanctions that has a significant effect on the timeliness of reporting individual annual tax returns.

The tax e-filing variable has a value of sig $=0.006$ $<0.05$ this means that the tax e-filing variable partially has a significant effect on the variable on the annual SPT reporting of individuals. Tax e-filing affects the timeliness of reporting the annual tax return of individuals because using e-filing means to report the annual tax return of individuals more quickly and efficiently to increase the timeliness of reporting the annual tax return of individuals.

E-filing has the most influence on annual SPT reporting when compared with two independent variables, namely the tax socialization variable and the tax sanction variable. Apart from the reasons that have been mentioned by the authors above, the big influence on annual SPT reporting can be seen in the value of standardized coefficients beta. The standardized coefficients beta value of tax socialization is 0.095 while the tax sanction is 0.181 and the biggest tax e-filing is 0.245 .

\section{Conclusion}

The researcher examines the effect of socialization, sanctions, and e-filing on the 2014 annual tax return report. The analysis uses the help of the SPSS program. The results of the study concluded as follows:

Tax socialization has no significant effect on annual tax return reporting. This means that accounting master students have understood and understood the filling of annual personal tax returns, how to report individual personal tax returns and legal basis related to individual annual tax returns. Awareness to participate in tax socialization to taxpayers who do not understand taxation still needs to be motivated so that taxpayer awareness increases to report annual tax returns of individuals.

2Tanks Tax has a significant positive effect on annual tax return reporting. This means that the more sanctions are enforced, the more timely the delivery of annual personal tax returns. Hypothesis H2 (tax sanctions affect the timeliness of the 2014 Annual Personal Tax Return Reporting) is accepted. The reason is that the more tax sanctions that are enforced or carried out will increase tax returns on time. This is in line with the assumption that if the tax sanctions are enforced or carried out strictly will greatly affect the compliance of individual taxpayers to pay taxes then report through the annual tax return of individuals. This assumption can be related to regulatory 
theory, which is a theory that emphasizes the existence of government intervention in the economic center for the public interest [2]. E-filing partially has a significant positive effect on the variable annual SPT reporting of individuals.

\section{References}

1. UU KUP No. 28 article 7, Regarding the third amendment to Law Number 6 of 1983 concerning General Provisions and Tax Procedures (2007)

2. J. Godfrey, A. Hodgson, A. Tarca, J. Hamilton, S. Holmes, Accounting theory (2010)

3. Mardiasmo, Perpajakan (revised edition), Yogyakarta Andi (2013)

4. U. Sekaran, Research Method for Bussines Fifth Edition. USA: John Wlley and Son (2003)

5. U. Husein, Cara Mudah Menyusun Skripsi, Tesis dan Disertasi, Bandung: PT Raja Grafindo Persada (2013) 